\title{
СУБ’ЄКТИВНЕ ВІДЧУТТЯ САМОТНОСТІ ОСІБ ПОХИЛОГО ВІКУ
}

Стаття присвячена аналізу особливостей суб'єктивного відчуття самотності осіб похилого віку. Самотність розглядається, як складний психологічний феномен, який свідчить про порушення реальних зв'язків і відносин особистості. Самотність є комплексним почуттям, на формування якого впливає ряд різноманітних факторів, як об'єктивних (вимушена ізолячія, зміна місия проживання), так і суб'єктивних (відсутність коханої людини, близьких друзів; відчуженість через непорозуміння з боку оточуючих; усамітненість). Суб'єктивні фактори $\epsilon$ визначальними у формуванні почуття самотності. Самотність є предметом досліджень філософії, психологї, суміжних наук. Актуальність аналізу почуття самотності спричинена важливістю даного явища, як в соціальному контексті, так і у внутрішньоособистісному.

Ключові слова: самотність, суб'єктивне відчуття самотності, особи похилого віку, базові потреби, осмислення сенсу життя, міжособистісні відносини, соиіальні стереотипи, самосвідомість, самопізнання, усамітнення.

Статья посвящена анализу особенностей субъективного ощущения одиночества пожильх людей. Одиночество рассматривается как сложный психический феномен, свидетельствуюший о нарушении реальных связей и отношений личности. Одиночество является комплексным чувством, на формирование которого влияет ряд различных факторов, как объективных (вынужденная изолячия, изменение места жительства), так и субъективных (отсутствие любимого человека, близких друзей; отчужденность из-за непонилания со стороны окружающих; уединенность). Субъективные факторы являются определяющими в формировании чувства одиночества. Одиночество является предметом исследований психологии, смежных наук, философии. Актуальность анализа исследования одиночества вызванная важности данного явления, как в социальном контексте, так и во внутриличностном.

Ключевые слова: одиночество, субъективное ощущение одиночества, престарелье, базовые потребности, осмысления смысла жсизи, межличностные отномения, соииальные стереотипы, самосознание, самопознание, уединения.

Постановка проблеми. Самотність $є$ складним і суперечливим феноменом, який у певних випадках пов'язаний із деградаційними процесами у розвиткові особистості, бо супроводжується відчуттям незадоволеності собою, своїм місцем в оточуючому світі, своїми відносинами. Самотність часто властива особам, які знаходяться у певних кризових ситуаціях, періодах змін, одним із яких вважають період похилого віку. Базовими потребами цього віку $є$ екзистенціальні та соціальні. Функціями перших $є$ пошук смислу життя, утримання структури сенсу життя, що розпадається, а других - формування і розвиток міжособистісних відносин.

Одним із важливих проявів соціальних потреб є наявність у людини відчуття близькості та єдності на противагу почуттю самотності. Самотність досить поширена саме у похилому віці, що зумовлено змінами у житті літньої особи, зокрема із тим, що вона залишає основне місце роботи, діти залишають батьківський будинок, втрачаються близькі люди (у першу чергу через смерть). Тобто, людина втрачає певний смисл життя та цінності, вона не відчуває себе суб'єктом життя, не задоволена ним, не здатна його адекватно оцінити. Вищезазначені втрати, на думку Л.А.Варави $\epsilon$ передумовою 
виникнення самотності[3]. Відповідно, одним із завдань нашого дослідження було проаналізувати особливості самотності у похилому віці, виявити чинники, від яких залежить переживання літньою людиною.

Аналіз останніх досліджень і публікацій. Проблема самотності ставала об'єктом уваги як західних, такі і вітчизняних філософів, психологів, соціологів, культурологів, письменників (О.О.Бодальова, Є.І.Головаха, Ф.М. Достоєвський, А. Камю, Ф. Кафка, С. К'єркегор, І.С.Кон, М.Ю.Лєрмонтов, А. Маслоу, М.М. Мовчан, Ф.Ніцше, Х. Ортега-і-Гассет, Н.В.Паніна, К.Роджерс, Ж.П. Сартр, 3. Фрейд, Е. Фромм, М. Хайдеггер, К. Хорні, Ю.М. Швалб, А. Шопенгауер, Е. Еріксон, К.Г. Юнг та інші). Слід зауважити, що психологія досліджує вияви внутрішньої самотності в психічному житті людини, тоді як філософія розглядає їх у людській екзистенції. О.Г. Коваленко підкреслює, що у суспільстві $є$ поширена думка, що проблема самотності найактуальніша у похилому віці [6]. Про це свідчать соціальні стереотипи. Так, один із стереотипів полягає у тому, що всі літні люди самотні. Аналогічний стереотип, наявний у свідомості всіх статево-вікових груп, виявила О.В. Краснова [5].

На думку С.В.Бакалдиного, почуття самотності пов'язане 3 переживанням ситуацій, суб'єктивно сприйнятих, як небажаних, неприйнятних для людини, із дефіцитом спілкування i позитивних відносин з оточуючими людьми. Самотності не завжди супроводжує реальна соціальна ізольованість індивіда. Можна постійно перебувати серед людей, контактувати 3 ними і разом 3 тим відчувати свою психологічну ізольованість від них, тобто переживати самотність [2]. Як зазначають Є.М. Заворотних та М.M. Мовчан, самотність є багатоплановим, амбівалентним психічним феноменом і може розглядатися як почуття, стан, процес, відношення. Як певний стан самотність виражає форму самосвідомості та засвідчує порушення реальних зв'язків і відносин внутрішнього світу особистості, відображає переживання своєї окремості, суб'єктивної неможливості чи небажання відчувати адекватний відгук, прийняття і визнання себе іншими людьми. Поява такого суб'єктивного переживання не залежить від обсягу міжособистісних контактів, стану психічного здоров'я, переважаючого емоційного настрою і зумовлюється особистісними властивостями особи [4; 7].

Аналізуючи феномен самотності, О.В. Неумоєва виділяє об'єктивну та суб'єктивну сторони (просторовий та психологічний аспекти). Перша відображається в об'єктивних відносинах і фактах, які у певних умовах стають деформованими. Відповідно проживаючи на самоті, літня особа може організувати власну життєдіяльність таким чином, що не почуватиметься самотньою, наприклад, читаючи багато літератури, займаючись улюбленим хобі, беручи участь у суспільному житті, отримавши «співрозмовника» у вигляді домашньої тваринки тощо. Друга - переживання особистості, які зумовлені деформацією іiі зв'язків з різними аспектами дійсності, порівняно незалежні від об'єктивних умов; вони володіють як позитивним, так і негативним потенціалом. Особа похилого віку, яка проживає з рідними, може бути їм байдужою і почуватися самотньою [9]. Також дуалістичний погляд на самотність виділення позитивних і негативних аспектів відображено у дослідженнях Г.Р. Шагівалєєвої [10]. Згідно Л.Ю. Айвазян, позитивний смисл у почутті самотності виділяють, коли його аналізують з точки зору добровільного усамітнення. У цьому випадку самотність виконує функції самопізнання, становлення саморегуляції, творчості та самовдосконалення, стабілізації психофізичного стану, захисту «Я» людини від деструктивних зовнішніх впливів. Дана самотність, дозволяє людині розібратися у власних переживаннях, сприяє пошукові смислу свого життя. Небезпечною, руйнівною $є$ негативна самотність, яка підпорядковує собі інші психічні процеси і стани, порушує внутрішню цілісність особистості, $є$ механізмом психологічного захисту, зумовлює формування надочікувань. Такі негативні прояви нівелюються, коли людина починає усвідомлювати їх, займає активну позицію у подоланні самотності [1]. У ході наукового пошуку 3'ясовано, що одні дослідники, зокрема (Т.К. Біксон, О.М. Коротеєва, К.І. Кутрон, С.Г. Резніков та ін.) вивчали ситуаційні детермінанти самотності: вдівство, розлучення, розрив стосунків, невисокий рівень соціальних зв'язків, особливості дитинства респондентів (розлучення батьків, взаємостосунки із матір'ю і батьком), зміна місця проживання, роботи, навчання. Інші науковці (С.П. Ільїн, І.С. Кон, В.М. Куніцина, Л.Е. Пепло, У.А. Садлер, В. Серма, І.М. Слободчиков та ін.) досліджували особистісні особливості самотніх людей: низька самооцінка, сором'язливість, інтроверсія тощо. За результатами досліджень було виявлено зв'язок між рівнем самотності, як суб'єктивного переживання, i різними психологічними особливостями людей (самопочуття, психологічні захисні механізми, мотивація досягнення успіху та/або уникнення невдач, смисложиттєві орієнтації, особистісні особливості). Дослідження проблеми самотності $є$ надзвичайно актуальними в контексті особливостей розвитку суспільства. Якісні зміни елементів культури, висока ступінь розшарування суспільства, роз'єднаність людей у великих містах, недостатність глибоких емоційних контактів - на ці та інші фактори звертають увагу науковці, які досліджують передумови до розвитку самотності. Розгляд проблеми самотності в контексті культури

Випуск 11, 2018. Збірник наукових праць РДГУ 
характерний для наукових праць Ф.Г. Майленовій, Л.Ф. Новицкій, Л.А. Колесникової, В. Молчанова, Т.В. Власової, В.І. Пузько. У статті «Культура і можливість подолання самотності сучасної людини» Л.Ф. Новицька, даючи культурологічний аналіз явища, зокрема вказує: «... Самотність людини в натовпі означає те, що вона не знайшла себе, що зв'язок ії з культурою якщо й $\epsilon$, то несуттєвий» [8, с. 8].

Отже, в даний час в психологічній літературі немає однозначного підходу до розуміння феномену самотності. Самотність розглядається різними вченими або як почуття, або як стан, а також як процес чи відношення. Велика увага приділяється розробці, аналізу, оцінці ефективності соціальнопсихологічних і психотерапевтичних методів допомоги людям, які гостро переживають самотність. Крім того, частина досліджень зачіпає і загальні, соціально-психологічні аспекти самотності. Таким чином, відзначаючи тенденцію до розширення і поглиблення вивчення самотності як предметної сфери, перш за все в рамках вітчизняної психологічної і соціальної наук, необхідно констатувати факт, що психологія самотності, як особлива галузь наукового дослідження, знаходиться на початкових стадіях свого розвитку.

Формулювання цілей статті. Постановка завдання полягає у здійсненні теоретикометодологічного аналізу феномену самоти та з'ясуванні особливостей його переживання особами похилого віку, які мають партнера або одинокі.

Виклад основного матеріалу дослідження. Почуття самотності здатне посилюватися або послаблюватися в залежності від динамічних змін в індивідуально прийнятих стандартах, інтенсивності ефективного міжособистісного спілкування або широти контактів з людьми, на які повинна йти людина. Стандарти подібного роду звичайно суб'єктивні, точно не визначені, але, загалом, непогано виражаються в судженнях типу: «Мені б хотілося мати більше друзів», «Ніхто посправжньому мене не розуміє» і т.п. Зменшення кількості друзів або контактів з людьми у тієї особи, яка раніше мала їх велику кількість, може сприйматися як посилення самотності.

Для встановлення особливостей суб'єктивного відчуття самотності особами похилого віку, зокрема чинників, які його зумовлюють (стать, сімейний стан) нами було проведено дослідження. У ньому взяло участь 60 людей віком 65-75 років, серед них 30 чоловіків та 30 жінок. Серед них $\epsilon$ досліджувані які є самотніми, живуть без родини (30 осіб), а інші 30 осіб, живуть 3 коханою людиною та рідними.

Таблиия 1

Суб'сктивне відчуття самотності людьми похилого віку

\begin{tabular}{|l|c|c|}
\hline \multirow{2}{*}{ Рівні самотності } & Чоловіки & Жінки \\
\cline { 2 - 3 } & кількісні показники & відсоткове значення \\
\hline високий рівень & 3 & 5 \\
\hline середній рівень & 19 & 31.7 \\
\hline низький рівень & 38 & 63.3 \\
\hline всього осіб & 60 & 100 \\
\hline
\end{tabular}

Як бачимо з таблиці у значної частини людей похилого віку переважає низький рівень суб'єктивного відчуття самотності. Це свідчить про те, що їм легко контактувати та заводити друзів, вони включені в соціальні відносини і зв'язки, активно комунікують з рідними та знайомими, можуть звертатися по допомогу та допомогати іншим. При цьому, п'ятій частині досліджуваних осіб притаманний середній рівень, тобто вони почувають себе ізольованими від інших, покинутими, не мають 3 ким поговорити, не знаходять порозуміння з рідними та оточуючими. Як правило дані особи переживаютьтакі емоційні стани, як: розпач, жалість до себе, нудьгу, відчуття власної непривабливості, сором'язливість. Як засвідчують результати наукових досліджень при виникненні почуття самотності гірше себе почувають і мають гірший настрій жінки. На відміну від чоловіків, вони також більше схильні переживати співчуття до себе і вразливість. Ті, хто проживає одиноко, складніше переносять стан самотності, ніж ті, хто живе з родиною. Крім того, перші при виникненні даного почуття гірше себе почувають, мають поганий настрій, їхня активність значно нижча, ніж у других.

Порівняємо значення за показником суб'єктивного відчуття самотності досліджуваних нами жінок і чоловіків похилого віку (див.табл.2). Як бачимо з даних таблиці, досліджувані жінки у похилому віці переживають самотність більшою мірою ніж чоловіки. Слід зауважити, що хоча різниця у даних не значна, проте чоловіки рідше відчувають самотність, менше зіштовхуються 3 такими емоціями, як відчай, депресія, нестерпний смуток, самоприниження, меншою мірою відчувають себе «білою вороною», «всіма покинутими». 
Суб'єктивне відчуття самотності чоловіками та жінками похилого віку

\begin{tabular}{|l|c|c|c|c|}
\hline \multirow{2}{*}{ Рівні самотності } & \multicolumn{2}{|c|}{ Чоловіки } & \multicolumn{2}{|c|}{ Жінки } \\
\cline { 2 - 5 } & $\begin{array}{c}\text { кількісні } \\
\text { показники }\end{array}$ & $\begin{array}{c}\text { відсоткове } \\
\text { значення }\end{array}$ & $\begin{array}{c}\text { кількісні } \\
\text { показники } \\
\text { значення }\end{array}$ & 1 \\
\hline високий рівень & 2 & 6.6 & 11 & 3.3 \\
\hline середній рівень & 8 & 26.7 & 18 & 60 \\
\hline низький рівень & 20 & 66.7 & 30 & 100 \\
\hline всього осіб & 30 & 100 & 1 & \\
\hline
\end{tabular}

Також ми звернули увагу на показники суб'єктивного відчуття самотності осіб похилого віку, які живуть усамітнено та з родиною (див.табл.3).

Таблиия 3

Суб’сктивне відчуття самотності осіб похилого віку, які мають різні соціальні умови проживання

\begin{tabular}{|c|c|c|c|c|}
\hline \multirow{2}{*}{ Рівні самотності } & \multicolumn{3}{|c|}{ Проживання з родиною } & \multicolumn{2}{|c|}{ Життя на самоті } \\
\cline { 2 - 5 } & $\begin{array}{c}\text { кількісні } \\
\text { показники }\end{array}$ & $\begin{array}{c}\text { відсоткове } \\
\text { значення }\end{array}$ & $\begin{array}{c}\text { кількісні } \\
\text { показники }\end{array}$ & $\begin{array}{c}\text { відсоткове } \\
\text { значення }\end{array}$ \\
\hline високий рівень & 1 & 3.3 & 2 & 6.6 \\
\hline середній рівень & 8 & 26.7 & 11 & 36.7 \\
\hline низький рівень & 21 & 70 & 17 & 56.7 \\
\hline всього осіб & 30 & & 30 & 100 \\
\hline
\end{tabular}

Як засвідчують дані досліджування, особи похилого віку, які живуть усамітнено, мають вищі показники суб'єктивного відчуття самотності, ніж ті, хто проживає 3 родиною. Очевидно, що і комунікативний потенціал людей похилого віку, які проживають 3 рідними значно вищий, що проявляється в кількісних і якісних характеристиках. Слід зазначити, що у більшості усамітнених осіб похилого віку коло постійного спілкування дуже вузьке (менше 3 осіб). При цьому особи похилого віку, що проживають з родиною, постійно контактують з 5-ма і більше людьми.

Висновки і перспективи подальших розвідок.

Отже, самотність є складним, багатоплановим, амбівалентним психічним феноменом, що, 3 одного боку, є детермінацією деформованого розвитку, а, з іншого, - ресурсом розвитку особистості. Його розглядають, як почуття, стан, процес, відношення та у ньому виділяють об'єктивну та суб'єктивну сторони (просторовий та психологічний аспекти). Поява даного почуття зумовлюється переживанням людиною своєї несхожості на інших, через що виникає певний психологічний бар'єр у спілкуванні, відчуття нерозуміння і неприйняття себе іншими особами.

Особливості переживання особами похилого віку самотності пов'язані із різноманітними психологічними та соціальними детермінантами. Більше ніж половина досліджуваних нами осіб похилого віку мають низький рівень суб'єктивного відчуття самотності. Це може свідчити про те, що вони мають риси, властиві інтровертам, відчувають оптимальну самотність і ставляться до цього явища позитивно; загальне самопочуття у них сприятливе. Однак, іншим досліджуваним особам притаманна самотність i, відповідно, переживання таких емоційних станів, як смуток, жалість до себе, сором'язливість. Нами також виявлено, що досліджуване почуття більше властиве тим літнім людям, які проживають усамітнено, ніж тим, хто проживає з родиною. Крім того, з'ясовано вищий рівень суб'єктивного відчуття самотності є в осіб похилого віку жіночої статі.

Проведений аналіз дозволив нам виявити особливості переживання літніми людьми почуття самоти відповідно до статі та сімейного стану. Перспективу подальших досліджень вбачаємо у виділенні вибірки осіб похилого віку, котрі проживають у місті та за його межами, мають різний освітній ступінь, що допоможе нам глибше проаналізувати суб'єктивне відчуття самотності осіб похилого віку.

\section{Список використаних джерел}

1. Айвазян Л. Ю. Взаємозв'язок суб'єктивного відчуття самотності і розвитку особистості / Л. Ю. Айвазян // Проблеми сучасної психології : зб. наук. пр. Кам'янець-Поділ. нац. ун-ту ім. Івана Огієнка, Ін-ту психології ім. Г. С. Костюка НАПН України / за ред. : С. Д. Максименка, Л. А. Онуфрієвої. - Кам’янець-Подільський : Аксіома, 2011. - Вип. 13. - С. 12-21. 
2. Бакалдин С. В. Эмоциональные особенности переживания одиночества / С. В. Бакалдин // Вестник Адыгейского Государственного Университета. - Майкоп : Изд-во АГУ, 2008. - Вып. 5. - С. 229-232.

3. Варава Л. А. Особливості переживання особистістю почуття самотності у стані соціальної депривації : автореф. дис. ... канд. психол. наук : 19.00.01 / Л. А. Варава. - Київ, 2009. - 20 с.

4. Заворотных Е.Н. Одиночество как психологический феномен / Е.Н. Заворотных // Материалы научно-практической конференции «Ананьевские чтения - 2006» / под ред. Л. А. Цветковой, А. А. Крылова. - СПб. : Изд-во С.-Петерб. ун-та, 2006. - С. 81-82.

5. Краснова О. В. Стереотипы пожилых и отношение к ним / О. В. Краснова // Психология зрелости и старения. - 1998. - № 1. - С. 10-18.

6. Коваленко О. Г. Суб’єктивне відчуття самотності осіб похилого віку / О. Г. Коваленко // Проблеми сучасної психології : зб. наук. пр. Кам’янець-Поділ. нац. ун-ту ім. Івана Огієнка, Ін-ту психології ім. Г. С. Костюка НАПН України / за ред. : С. Д. Максименка, Л. А. Онуфрієвої. Кам'янець-Подільський : Аксіома, 2013. - Вип. 19. - С. 239-250.

7. Мовчан М. М. Самотність, як феномен буття особистості : монографія / М. М. Мовчан. Полтава : РВВ ПУСКУ, 2009. - 265 с.

8. Новіцка Л.Ф. Культура і можливість подолання самотності сучасної людини/ Л. Ф. Новіцька // Периферійність в культурі XX століття : матеріали Всерос. наук.-практ. конф. Пермь, 2001. - С. 32-43.

9. Неумоева Е. В. Одиночество как общественно-историческое явление и как явление индивидуальной жизни / Е. В. Неумоева // Гуманитарный вектор : вестн. Забайкал. отд-ния Акад. гуманит. наук. - Чита : Изд-во ЗабГПУ. - 2004. - № 1-2 (10-13). - С. 23-29.

10. Шагивалеева Г. Р. Одиночество и особенности его переживания студентами : монография / Г. Р. Шагивалеева. - Елабуга : Изд-во ОАО «Алмедиа», 2007. - 157 с.

\section{References}

1. Ajvazyan L. Yu. Vzayemozv'yazok sub'yekty`vnogo vidchuttya samotnosti i rozvy`tku osoby`stosti / L. Yu. Ajvazyan // Problemy` suchasnoyi psy`xologiyi : zb. nauk. pr. Kam'yanecz`-Podil. nac. un-tu im. Ivana Ogiyenka, In-tu psy`xologiyi im. G. S. Kostyuka NAPN Ukrayiny` / za red. : S. D. Maksy`menka, L. A. Onufriyevoyi. - Kam'yanecz`-Podil`s`ky`j : Aksioma, 2011. - Vy`p. 13. - S. 12-21.

2. Bakaldin S. V. Jemocional'nye osobennosti perezhivanija odinochestva / S. V. Bakaldin // Vestnik Adygejskogo Gosudarstvennogo Universiteta. - Majkop : Izd-vo AGU, 2008. - Vyp. 5. - S. 229-232.

3. Varava L. A. Osobly`vosti perezhy`vannya osoby`stistyu pochuttya samotnosti u stani social`noyi depry`vaciyi : avtoref. dy`s. ... kand. psy`xol. nauk : 19.00.01 / L. A. Varava. - Kyyiv, 2009. - $20 \mathrm{~s}$.

4. Zavorotnyh E. N. Odinochestvo kak psihologicheskij fenomen / E. N. Zavorotnyh // Materialy nauchno-prakticheskoj konferencii «Anan'evskie chtenija - 2006» / pod red. : L. A. Cvetkovoj, A. A. Krylova. - SPb. : Izd-vo S.-Peterb. un-ta, 2006. - S. 81-82.

5. Krasnova O. V. Stereotipy pozhilyh i otnoshenie k nim / O. V. Krasnova // Psihologija zrelosti i starenija. - 1998. - № 1. - S. 10-18.

6. Kovalenko O. G. Sub'yekty`vne vidchuttya samotnosti osib poxy`logo viku / O. G. Kovalenko // Problemy` suchasnoyi psy`xologiyi: zb. nauk. pr. Kam'yanecz`-Podil. nac. un-tu im. Ivana Ogiyenka, In-tu psy`xologiyi im. G. S. Kostyuka NAPN Ukrayiny` / za red. : S. D. Maksy`menka, L. A. Onufriyevoyi. Kam'yanecz`-Podil`s`ky`j : Aksioma, 2013. - Vy`p. 19. - S. 239-250.

7. Movchan M. M. Samotnist', yak fenomen buttya osoby`stosti : monografiya / M. M. Movchan. Poltava : RVV PUSKU, 2009. - $265 \mathrm{~s}$.

8. Noviczka L. F. Kul'tura i mozhly`vist` podolannya samotnosti suchasnoyi lyudy`ny` L. F. Novicz`ka // Pery`ferijnist`v kul`turi XX stolittya : materialy` Vseros. nauk.-prakt. konf. - Perm`, 2001. S. 32-43.

9. Neumoeva E. V. Odinochestvo kak obshhestvenno-istoricheskoe javlenie i kak javlenie individual'noj zhizni / E. V. Neumoeva // Gumanitarnyj vector : vestn. Zabajkal. otd-nija Akad. gumanit. nauk. - Chita : Izd-vo ZabGPU. - 2004. - № 1-2 (10-13). - S. 23-29.

10. Shagivaleeva G. R. Odinochestvo i osobennosti ego perezhivanija studentami : monografija / G. R. Shagivaleeva. - Elabuga : Izd-vo OAO «Almedia», 2007. - 157 s.

\section{ELDERLY PEOPLE}

N. V. Kurylliuk-Delcheva, N.M. Gutsulyak SUBJECTIVE FEELING OF LONELINESS IN

The article is dedicated to the analysis-signs of the subjective sense of loneliness of the elderly people. Loneliness is seen as a complex mental phenomenon, which indicates a violation of real connections and 
relationships of the individual. Loneliness is a complicated feeling, the formation of which is influenced by a number of different factors, both objective (forced isolation, change of place) and subjective (lack of a loved one or close friends, alienation due to misunderstanding of others, solitude, etc.). Subjective factors are decisive in shaping the sense of loneliness. Loneliness is the subject of research in philosophy, psychology, related sciences. The importance of the analysis of the feelings of loneliness is due to the importance of this phenomenon, both in the social context and in the internal personal context.

Key words: loneliness, subjective sensation of loneliness, elderly people, basic needs, understanding of life, interpersonal relationships, social stereotypes, identity, solitude and privacy. 